\title{
Adaptation in Foreign Policy of Singapore Towards ASEAN
}

\author{
Anna Grzywacz \\ Faculty of Business and International Relations, Vistula University, Warsaw, Poland
}

\section{Email address:}

anna.y.grzywacz@gmail.com

\section{To cite this article:}

Anna Grzywacz. Adaptation in Foreign Policy of Singapore Towards ASEAN. Humanities and Social Sciences. Vol. 3, No. 5, 2015, pp. 240-248. doi: 10.11648/j.hss.20150305.22

\begin{abstract}
Singapore is one of the most important countries in Asia-Pacific region and one of the most powerful in Southeast Asia. Singapore serves as leader in the Association of Southeast Asian Nations (ASEAN). The analysis uses the political adaptation theoretical framework to analyze Singaporean activity. The paper attempts to answer the question what is the political strategy adopted by Singapore in its activity in the ASEAN? The purpose of the analysis is to verify the argument that adaptation policy of Singapore may be characterized by its creativity, what means that the state seeks to adapt to changes in the international environment. At the same time the state attempts to shape the international system.
\end{abstract}

Keywords: Adaptation, Foreign Policy, Singapore, ASEAN

\section{Introduction}

Singapore is one of the most economically powerful countries in the world as well as one of the most important players in the East Asian region. The studies analyzing the Singaporean policy basically focus on two aspects of its functioning in international relations-the country's developmental model [1] and approach of the state to the political liberalism [2].

Issues concerning national affairs of Singapore are well described in the literature [3]. However, there is not many studies on foreign policy and international activity of the Singaporean state. In the past several years only a few monographs about the issue of international activity of Singapore was published [4]. Due to the shortage of the works in this area this article discusses Singaporean foreign policy.

The paper attempts to answer the question what is the political strategy adopted by Singapore in its activity in the Association of Southeast Asian Nations (ASEAN)? The purpose of the analysis is to verify the argument that adaptation policy of Singapore may be characterized by its creativity, what means that the state seeks to adapt to changes in the international environment. At the same time the state attempts to shape the international system.

The article is divided into three parts. The first part presents the adaptation in foreign policy concept. The second part describes the vision of the foreign policy of Singapore and the perception, role and importance of ASEAN for
Singaporean state. The last section is concentrated on the two aspects of the adaptation in the Singapore's foreign policy economic relations on the example of the free trade agreements and human rights issues in the ASEAN, including involvement in the political changes taking place in Burma.

\section{Method - Theoretical Framework}

Adaptation is a very broad category. It requires clear definition and categorization in the analysis due to the ambiguity of the term. Adaptation is the most often understood as a process of adaptation to environmental entity depending on the condition of the environment and the needs of the entity. James N. Rosenau, who started working on the adaptation in foreign policy defined it as an action to preserve and protect social structures and characteristics of the state and of its being [5].

The definition may be expanded on the element of a state influence on the environment and thus concluded that adaptation of a state action aims at preserving the balance between the needs and interests of the state and the requirements coming from the international and national political environment [6]. In the following part of the paper political adaptation will be understood according to this definition.

A characteristic feature of the Rosenau's works is that he did not attribute great importance to internal and external factors in the political studies. He believed that attention should be paid on the existence of interactions and 
interdependencies between the state and its internal attributes and the environment in which the state operates [7]. This assumption meant that the analysis should be focused on the two aspects of the functioning of a state - the environment in which it is active and process of identifying the opportunities to adapt in the changing environment [8].

According to the researcher, depending on the type of changes that occur in the internal and external environments, there are four types of foreign policy: habitual, deliberative, spirited and convulsive.

Habitual foreign policy occurs when there are small changes in the internal and external environment. They do not enforce the transformation of policy and allow for the continuation of the preferred policy by the country. Deliberative foreign policy refers to the situation of major changes in the external environment and small in the internal environment. There is thus the possibility of a sensible approach to the situation and foreign policy. Spirited policy is the result of major changes in the internal environment, although there are no significant changes in the external environment, while convulsive policy refers to the situation when major changes occur in both environments [9].

The assumptions presented by James N. Rosenau have been criticized [10]. Attention has been paid primarily on the deterministic approach in his works. Foreign policy is in fact dependent not only on the "change" which can be variously understood and evaluated but also on factors such as the political system, political culture, strategic and national identity or economic and developmental model [11]. Criticism stressed also the ambiguity and the difficulty of defining the term of a political adaptation.

In response to the criticism J.N. Rosenau completed the concept of adaptation in foreign policy. The scholar included the roles of the state and individuals, the size, structure and level of economic development of the state and role of institutions shaping the content of foreign policy. These factors influence the adaptive capacity of the state. Depending on the circumstances there are four types of adaptation: acquiescent, intransigent, promotive and preservative. Depending on the type the state chooses the model of political behaviour [12]. Acquiescent attitude defines the situation of converting the state's internal structures due to the expectations or pressures coming from the external environment. Intransigent attitude means the situation of ignoring the impact of the international environment on internal and external policies. Promotional attitude is an expression of willingness to cooperate with the international community and the conservative attitude is focused on maintaining stability and the balance between internal and external environment [13].

Another classification of the concept is three adaptation strategies of the state: passive, creative and active [14]. Passive strategy refers to the adaptation and absorption of the changes from the international environment. Creative strategy describes the development of both communities, internal and external, but also including the changes flowing from these environments. This is the optimal type of adaptation since it is a continuous searching for the balance between the environments. Active strategy is a desire of selfdevelopment in international relations with refusing to adapt to changes occurring. The state seeks to pursue its own political goals [15].

The theory of adaptation despite its criticism is a useful analytical framework and perspective as it allows to determine: 1. how the international environment affects the state and politics?; 2 . what is the state's capacity to respond to changes in the international environment?; 3 . and what is the relation of this response with the important values for the state, inter alia interest of the state? [16].

\section{Results}

\subsection{Vision and Aims of Singaporean Foreign Policy}

Due to the small territorial size and population potential but also the rapid economic development policy Singaporean politics is frequently characterized by the category of ideology of survival. For Singapore, which gained independence in 1965, the issue of security was paramount [17]. In economic terms Singapore is associated with the concept of a "Global City" - the term used by the former foreign minister Sinnathamby Rajaratnama in 1972[18]. The motivation to adopt this kind of a policy was a result of the need to ensure the viability of the state. The politicians decided that - to accomplish this goal - there is a need to create a strategy - construct the strong relationships in the rapidly evolving international economy. This meant taking into account international changes and not to focus just on the regional development but also international [19].

After becoming independent country in 1965 due to the difficult political and economic situation Singapore adopted the strategy of "positive neutrality". It meant adopting the policy, which would allow Singapore to not become the object of rivalry but also to "staying out of 'any competition, or conflict between the power blocs,' but where the 'survival, security, or prosperity' of 'an independent, democratic, noncommunist Singapore (including Malaysia) is threatened she cannot be neutral"' [20].

Singapore's foreign policy is focused primarily on economic and international issues that are important from the point of view of Singapore. The problems concerning culture or the perception of political liberalism are not often raised in political discussions. In this case the way how the policy is shaped is influenced by the historical conditions [21]. History became the basis of concerns about the survival of the state, then the political recognition of the primacy of pragmatism over the other principles in international relation [22].

Former Singapore's foreign minister (1980-1988) Suppiah Dhanabalan identified four basic characteristics of the Singaporean foreign policy: 1. maintaining contacts with any country that will express willingness to work together; 2. maintaining economic relations in any situation, if it brings benefits; 3 . neutrality in the rivalry between the blocks; 4 . developing relations with ASEAN countries in order to 
strengthen the importance of the region in international relations [23]. In subsequent years the concept of foreign policy has been changed. Politicians stopped to use the ideological factor as one of the most important in the politics and focused on pragmatics [24].

Small states perceive their role in international relations differently than the big political players, as well as they look differently at the key issues for every state, inter alia national or economic security. Most of the small states, including Singapore, are concerned with the security issues, especially the threat of being incorporated. The concerns were based primarily on the size and population potential, other factors were not seen as important as the size and population. Despite these features - what is often stressed in the Singapore's presence in international relations - the state is active. Activity in politics is not however a typical feature of a small state [25].

This understanding of the policy may be reflected by the words of Tommy Koh, Singaporean diplomat who stated "the norm is for small states to be reactive rather than proactive to be the subject of the actions of the big states instead of being the actors and to accept their fate as small states"[26]. It corresponds with the creative adaptation strategy of the Singaporean state. According to the politician important feature of Singapore's foreign policy is to defend the interests of the state. This is important because small states are struggling with forcing initiatives and during the decisionmaking process as they cooperate with much stronger countries [27].

Singaporean politicians might be categorized in the most of the cases as realists. The realistic understanding of international relations is present in the speeches and discussions. Most of the works that analyze the Singaporean politics suggest that realism is the theory that fits and explains Sinagapore's political behaviour the most accurately [28]. Another characteristic is a political commitment and respect for international law.

Tommy Koh believes, however, that this is not realism but pragmatism what is the most useful to explain Singaporean political activity. Politician explicitly recognized that "our adherence to international law is based upon utility and not morality" [29]. This is due to the fact that a small country has more advantages when the international community respects the principles and international norms as relations are based on the law, not on the strength or power [30].

The basic principles of the foreign policy of Singapore is the belief that due to the size and geographical location of the state it has limitation in international relations thus the state is aware of its place in international relations. Singapore avoids alliances that could change the regional balance. Goh Chok Tok, prime minister of Singapore, described the philosophy as "a unique survival strategy of a unique state". The basis is the belief that the best solution is to maintain the status quo. This strategy, however, does not translate into economic relations as Singapore is working in every field, which help to develop Singaporean economy [31].

Singapore is working closely with its closest neighbours in the region, it acts as defender of its most important partners and fully supports the activities and the development of ASEAN. Among the priorities are also listed issues and goals of ensuring security in Southeast Asia and throughout the Asia-Pacific region. The basis remains the maintenance of a free and open trading system, as well as Singapore is willing to cooperate with every partner if it brings benefits and positive impact on the open market economy. The last priority is to engage more with the United Nations (UN) and other international organizations [32].

Singapore is committed to - among others - in many peacekeeping missions organized by the UN [33]. Impression of the greater involvement in international affairs can also be made due to the establishment of the Singapore International Foundation (SIF) in August 1991. The aim of this institution is to play a more dynamic and responsible role in the international arena. Although the main task of the SIF is to maintain contacts with Singaporean abroad, it is also responsible for the development of Singapore's peacekeeping force and to be able to offer humanitarian aid to the least developed countries in the world [34].

More dynamic activity is also reflected in the increased ability to offer technical assistance (mainly in terms of human resources) to other countries, including China, which expressed a desire to learn from the positive experience of Singapore. During the last decade, about 21500 foreign participants from over 87 countries received technical support and training programmes. The cooperation includes offering the programmes through the United Nations and other organizations: ASEAN and the Colombo Plan. Singapore has also initiated a program of cooperation with other countries, like Japan, to conduct technical training for developing countries in Asia and Africa [35].

\subsection{Role and the Meaning of ASEAN to Singapore}

Singapore is a founding member of the ASEAN, which was established on August 8 of 1967. Due to the small size of the state and its political interests Singaporean state supports the development of the organization. After gaining the independence Singapore focused more on the international situation rather than on regional issues. This is why Singapore was so often criticized for its wait-and-see policy towards organization.

When the war in Vietnam started and after its acquisition by the communists in 1975, Singapore began to look differently at the ASEAN. This was due to the fact that the organization had a resources to become a defence block against communism. The case of Kampuchea and determined attitude of Singapore showed that despite the small size of the state the country may be active. The ASEAN helped Singapore to play a major role. It was important for this country to withdraw foreign troops from Kampuchea. In 1981, with Malaysia and Indonesia, Singapore called for their withdrawal. Singapore was also active during a special conference on Kampuchea in 1981. Later, Singapore hosted a trilateral meeting between delegates of the Khmer Rouge, a former prime minister of Kampuchea Son Sann and the 
prince of the nation Sihanouk [36]. At the same time Singapore adopted anti-Russian stance, thus the state tried to influence the political situation in the region. It means that already in the eighties of $20^{\text {th }}$ century Singapore started to show its activity, what is the characteristics of the creative adaptation strategy.

The process of integration, particularly economic dimension of integration, has been the most important to Singapore. The pace of the integration was not satisfactory for Singaporean government for more than twenty years since the foundation of the organization [37]. Singapore was named the state, which is the richest in the region but has not been able to help their neighbours. Singapore has begun slowly to change its policy and focuses more not only on internationalism but also regionalism. The Singaporean government treats these processes as complementary [38].

For Minister S. Rajaratnam ASEAN's most important function was the possibility to cooperate, what allows to reconcile the national and regional interests [39]. Singapore looks at the ASEAN primarily through the prism of the possibility of its own development [40]. Minister of Foreign Affairs of Singapore (1988-1994) Wong Kan Seng mentioned the acceleration of regional cooperation of ASEAN as the second most important foreign policy objective of Singapore, next to the sovereignty and its protection. The third was the stability and balance of power in the Southeast Asian region [41].

In international relations in Southeast Asia ASEAN is especially important as it is the only one mechanism of the dialogue between the countries. The organization is criticized for not being able to manage the most important regional issues (inter alia non-traditional security threats) but also positively assessed (inter alia resolving problems and disputes without using the force) [42]. The mechanism of dialogue is the most important instrument because it has become the constitutive norm in the organization [43]. ASEAN standards are difficult to characterize. This is due to the relatively low degree of institutionalization of this organization, but also many informal procedures [44]. Amitav Acharya characterizes them as follows: 1. noninterference in internal politics; 2 . the non-use of force to resolve conflicts; 3 . protection of regional autonomy; 4 . adoption of the ASEAN Way principle [45].

The end of the ideological rivalry between East and West coincided with a growing interest in issues such as human rights, environmental protection and democratization. Singapore sees these issues as the main challenges facing the ASEAN. Singapore's stance on human rights and democratization implies: 1 . rejection of Western claims about the universality of human rights; 2 . opposition to any attempt to impose political models or solutions; 3 . rejection of tying human right with aid programmes conducted by Western countries; 4. highlighting certain selected elements of the system of human rights protection and promotion; 5 . recognition of economic development as a factor positively affecting the social order and stability. Singaporean leaders recognize the growing problem of conflict arising from cultural differences (mainly in reference to democratic values and human rights), which may ultimately lead to a new "cold war". It should be noted, however, that Singapore is less sensitive and vulnerable to the pressures coming from the West on human rights due to the lack of a need to receive foreign international aid and a lack of internal conflicts. It does not attract the attention of "the international community" and the media just like in the cases of some other countries. There is, however, less doubts about the fact that Singapore's foreign policy becomes more sensitive to the growing "politicization" of these issues. This in turn could adversely affect the international image of Singapore, including political and economic interests [46].

\section{Discussion}

The development of economic relations is a priority of Singaporean foreign policy. The issues of human rights and democratization of the ASEAN and countries that are members of this organization is recognized as one of the major challenges in the region. The processes of adaptation politics of Singapore will be provided in regard to these two issue. In both cases, Singaporean foreign policy has the characteristics of flexibility, it adapts to the changes taking place in the region, but in conformity with the interests of the state.

\subsection{Economic Dimension of Singaporean Politics}

In the matter of economics, Singapore is an advocate of liberalization as this is the most advantageous for the country. Singaporean state as one of the economically strongest countries in Southeast Asia is involved in many initiatives that support the processes of liberalization of the markets. Singapore enhances the ASEAN Economic Community, Asia-Pacific Economic Cooperation (APEC) and the AsiaEurope Meeting (ASEM), which are treated as complementary by Singapore.

Singapore signs many free trade agreements (FTAs) with countries outside the ASEAN, such as: New Zealand, Japan, the European Union (EU), Australia and the United States. Singapore regularly conducts negotiations with other countries. As pointed out by Singaporean government agreements are not a substitute for regional or global agreements but are complementary [47].

Singapore, in principle, is an advocate and promote free trade at global and regional level, but the involvement into bilateral free trade agreements is, at least for several reasons: 1. integration at the regional level is rather slow, which does not make it as favourable as Singapore expects [48]; 2. the ASEAN slowly negotiates cooperation in free trade with such countries as the United States, Japan and the European Union, which are very important partners from Singapore's point of view; 3. pace of liberalization of trade between North and South (and the signing of the North American Free Trade Agreement, NAFTA) has become a driving force in acceleration of the economic processes in the region; 4. FTAs are not just economic interests but also of strategic 
importance to Singapore; 5. signing the FTAs also means the protection in a situation where the pace of liberalization and market integration does not meet expected requirements, especially in the context of the WTO negotiations.

Singapore's approach and balancing between the FTA and the ASEAN Free Trade Agreement (AFTA) is variously commented by the countries in the region. For some countries such behaviour means the weakening of the formation of AFTA and some countries believe that it may hamper cooperation within the organization and with the strategic partners. Quite a strong opponent of such a policy and a critic of Singapore is Malaysia [49]. Studies suggest that Singapore is the country that can the most benefit from trade liberalization [50]. Singapore seeks to promote multilateralism in the region through cooperation with powers such as China and India - the countries that has already closely been cooperating with the ASEAN [51].

Singapore's economic achievements were possible primarily because of the process of globalization. Singaporean turn to regionalism is seen as an important stage in the development of the national economy. The country is increasingly investing in the Asia-Pacific region. It means not only strengthening economic ties but also the development of individual markets, primarily in Southeast Asia [52]. Singaporean concept of regional cooperation is broad and flexible - the subregional cooperation concerns Malaysia and Indonesia, the regional dimension refers to the ASEAN, and last one covers entire Asia-Pacific region [53].

At the subregional level Singapore promotes the concept of regionalism driven by economic factors (market-driven regionalism). This is the response to unsatisfied Singapore's need of the level and pace of the economic integration in the ASEAN [54]. Singaporean idea of "growth triangle" which includes Singapore, Batam and Riau belonging to Indonesia and Johor in Malaysia aims to combine the financial services offered by Singapore with relatively cheap labour forces in other regions. On this basis they can attract foreign investors, while the territories can develop [55].

During the first years after the ASEAN's foundation, the organization did not serve first and foremost to economic integration. More important were issues of safety and security in the region, especially in the relations with stronger countries. Security was the most important. Initially, Singapore also had not increased significantly the trade with the countries of the organization. The ASEAN countries became important in the economic sense in the nineties of the twentieth century.

Singapore has always insisted on the market liberalization in the ASEAN. After the first summit in Bali in February 1976, Singapore became a leader in intraregional trade liberalization. Singapore is basically the only country that fulfils its commitments to liberalize market on time, completely eliminates tariffs on all goods in bilateral trade and minimizes restrictions on investments coming from ASEAN to Singapore [56].

Singapore is committed to not only economic development, but it is also a country that established close relations with other countries. Since 2000, Singapore has signed many agreements, like FTA among ASEAN countries, including major economic powers like Australia, China, Korea, Japan or the United States, but also with smaller countries such as Jordan, Panama and the organization - Gulf Cooperation Council (GCC) [57]. Singaporean state has also worked closer with China and India [58].

Singapore has never paid too much attention to cultural issues. It is more often raised in public speeches. The question of identity is one of the subjects that needs to be discussed by the politicians. The issue of identity is often raised in the context of the acceleration of regional integration [59]. In some works, a problem of identity and the ability to shape the regional identity is treated as one of the most important requirements for further cooperation in the region [60]. Societies in ASEAN's countries do not have much trust to regional institutions. In the case of Singapore particularly noticeable is scepticism of society towards the ASEAN [61].

Singapore is sometimes portrayed as a country that prefers to balance in the region, is sceptical towards the ASEAN and reluctant to the idea of the identity of the organization [62], but pragmatic in the regional cooperation. Utilitarianism is still valued by politicians in Singapore as the basis of the state activity. This approach was characterized by the foreign minister of Singapore (2004-2011) George Yeo who said that the driving force of regional cooperation within ASEAN is not sharing a common identity, but the shared challenges facing the organization [63].

Due to the factor that could become an obstacle to regional cooperation, Singaporean politicians stress the issue of the need to shape the ASEAN identity. "Search for identity" is the title of a book written by George Yeo who recognizes that the organization should develop a common strategic response to changes in the economic environment. What needs to be developed as well is a sense of the ASEAN identity, which would result in the strengthening of the organization. On August 8 of 2005 for the first time was celebrated the day of the ASEAN. Prime Minister of Singapore Lee Hsien Loong commented the event and stated that the organization is forced to make people identify with the ASEAN as the future of the organization depends on that matter [64].

Highlighting the social and ideational factors is new in the sense the foreign policy of Singapore is the most often referred as a realistic or pragmatic [65]. Singaporean politicians' statements about the identity of the ASEAN are by some considered as only the rhetoric. It is difficult to analyze the policy of Singapore without regard to identity issues, ideas or processes of socialization [66]. These issues have begun to be seen as necessary in the integration process, including its economic dimension, which is most important for Singapore.

\subsection{Human Rights and Democratization}

The issue of protection and promotion of human rights does not appear as a priority of ASEAN. More important issues remain security problems, economic cooperation and 
socio-economic development. Human rights were not seen as an important element for the development of the organization, they were separated from economic issues and therefore marginalized. This does not mean that Singapore completely ignores this issue, the country sees the need to shape the identity of ASEAN, while human rights are by some countries appreciated and treated as the basis of political and social life. In 2009 ASEAN Intergovernmental Commission on Human Rights (AICHR) was set up, what is the firsy step towards humenr right protection mechanism [67].

In Singapore, there is at least a few organizations that work in the field of human rights promotion. One such a group is Maruah, which implements programs aimed at raising awareness of the importance of human rights at the local, but also participates in broader regional discussion [68]. There are also other organizations, inter alia Association of Women for Action and Research (AWARE), which was founded to support women [69].

Singapore did not deny nor disapproved the creation of a mechanism to protect human rights in ASEAN. The attitude of the Singapore can be called wait-and-see policy. Depending on how the mechanism would operate and be shaped Singapore gives its opinion. However, it may be stated that Singaporean country already expressed its - at least preliminary - support for this mechanism in 2007 [70].

In 2014, Lee Hsien Long, in response to a question about how Singapore sees human rights, stressed that each country has a different perspective. The United States with its history, constantly highlighting the importance of human rights, emphasizes the importance of these values. Countries of Southeast Asia appreciate freedom and wealth, but they also have other priorities. More important it is to ensure the development of society. For this reason, Singaporean prime minister looks at the democracy and human rights in a pragmatic way - whether these values help to ensure prosperity and stability [71].

Singapore engaged in a process of political changes in Burma. Singapore's activity is based on at least three reasons. Firstly, Singaporean politicians are trying to improve its international image [72]. Singapore is in a different situation than other countries because it is not adjacent to Burma, it is not fully democratic state. Hence, it looks differently at issues of personal freedom and political rights. Singaporean state is also not a close ally and partner of this country. Burma is more important for Indonesia and Malaysia, but Singapore by engaging in regional affairs, can show its commitment and improve its image in terms of democracy for which is often criticized. Secondly, Burma is a significant country because it is an important trading and investment partner for Singapore at the regional level. In addition, violations of human rights and improving the situation in Burma on international arena worsen the image of Burma and the region, thus it reduces the attractiveness of the region and could adversely affect regional investment. Thirdly, the increasingly open criticism of Burma by countries in the region, including Indonesia and Malaysia helped Singapore to express its concern about the situation in that country [73].

Most countries have recognized the need to collectively resolve problems arising from the political changes taking place in Burma. The ASEAN members started to cooperate on 2003. The ASEAN joint action was reinforced in 2006 when Burma was about to take the lead in the organization. Due to concerns that the leadership of that country would not have a positive impact on the perception of the ASEAN, the leadership was blocked. Prime Minister of Singapore, Lee Hsien Loong, said then that "ASEAN would be marginalized" if they would have not taken adequate measures [74].

In the regional dimension, despite concerns about the situation in Burma, Singapore has not expressed support for the decision to enable to join the junta into the process of resolving the situation in Burma, in contrast to countries such as Indonesia and Malaysia. Singapore prefers to maintain the principle of non-interference in the internal affairs of other countries as a basis for functioning in international relations in the region [75].

It can therefore be concluded that Singapore's foreign policy focuses primarily on issues that promote economic development, the issue of political liberalism (or human rights) is not seen as important in politics. Singapore's attitude towards the development of the mechanism of human rights in ASEAN can be a sign that the Singaporean politicians are becoming less sceptical about this concept, even though political actions are most often based on pragmatic calculations.

\section{Conclusion}

Singapore as a small country uses many instruments to influence the international relations. Singapore has limited capacity to use the "hard power". Therefore, Singaporean state has used the soft power. As noted by H.C. Chan "soft power strategy is in many cases a necessity, not the possibility that the state can use" [76].

Despite the limitations resulting from the specific functioning of the small state in international relations, Singapore seeks to actively shape and influence the changes in the regional environment, while adapting to changes in the international environment. For this reason it can be concluded that Singapore has adopted a model of creative adaptation, which primary characteristic is to balance the changes in the environment. This is particularly clear in the case of development of economic relations and in relations to the issue of human rights and democratization in the ASEAN.

Changes in the international and regional environment influence the foreign policy of Singapore. In the case of economic relations and unsatisfactory progress of market liberalization Singapore has been attempting to accelerate further development by initiating programs that support these processes. Singaporean politicians are sceptical when it comes to assess democratic values and the mechanism of human rights protection. Nevertheless, they react to these regional changes regarding them as an inevitable. It can 
therefore be concluded that Singapore has the ability to respond to changes in the environment, even though not all of them are compatible with the interests of the state. Singapore does not recognize the universality of human rights and democratic values and therefore seeks to "protect" the region against sudden changes. It should be noted, however, that Singapore's foreign policy is not susceptible to internal pressures, because there is no powerful groups that could exert such pressure. Singaporean politics is the most focused on the economic development. This has not been changed for the last years, however the approach how to achieve this goal has been changing accordingly to changes in the international environment.

\section{References}

[1] T. Chong (ed.), Management of Success: Singapore Revisited, Singapore: Institute of Southeast Asian Studies, 2010; W.G. Huff, The Economic Growth of Singapore: Trade and Development in the Twentieth Century, Cambridge: Cambridge University Press, 1994; E.H. Schein, Strategic Pragmatism: the Culture of Singapore's Economic Development Board, Cambridge: Cambridge University Press, 1997; J. Sung, Explaining the Economic Success of Singapore: the Developmental Worker as the Missing Link, Cheltenham: Edward Elgar, 2006; C.A. Trocki, Singapore: Wealth, Power and the Culture of Control, Oxon-New York: Routledge, 2006; P. Wilson, Economic Growth and Development in Singapore, Cheltenham: Edward Elgar, 2002.

[2] See J.B. Tamney, The Struggle Over Singapore's Soul: Western Modernization and Asian Culture, Berlin: Walter de Gruyter, 1995; H.C. Chan, The PAP and the Structuring of the Political System, in: K.S. Sandhu, P. Wheatley (eds), Management of Success: The Moulding of Modern Singapore, Singapore: Institute of Southeast Asian Studies, 1989; M. Hill, 'Asian Values' as Reverse Orientalism: Singapore, "Asia Pacific Viewpoint" 2000, vol. 41, no. 2; K.E. Kuah, Confucian Ideology and Social Engineering in Singapore, "Journal of Contemporary Asia” 1990, no. 20.

[3] B.H. Chua, Communitarian, Ideology and Democracy in Singapore, London-New York: Routledge, 1995; M. Hill, K.F. Lian, The Politics of Nation Building and Citizenship in Singapore, London-New York: Routledge, 1995; L. Kong, B.S.A. Yeoh, The Politics of Landscapes in Singapore. Constructions of "Nations", New York: Syracuse University Press, 2003; T. Lee, The Media, Cultural Control and Government in Singapore, London-New York: Routledge, 2010; D.K. Mauzy, R.S. Milne, Singapore Politics Under the People's Action Party, London-New York: Routledge, 2002; H. Mutalib, Parties and Politics: A Study of Opposition Parties and PAP in Singapore, Singapore: Eastern Universities Press, 2004; J.S.T. Quah, Combating Corruption Singapore-style: Lessons for other Asian Countries, Baltimore: School of Law, University of Law, 2007; J.S.T. Quah, Public Administration Singapore-style, Bingley: Emerald Group Publishing, 2010; K.Y.L. Tan, An Introduction to Singapore's Constitution, Singapore: Institute of Southeast Asian Studies, 2005; L. Thio, K.Y.L. Tan (eds), Evolution of Revolution: Forty Years of the Singapore Constitution, Oxon-New York: Routledge, 2009; R. Worthington, Governance in Singapore, London: Routledge 2003.

[4] B. Singh, The Vulnerabilities of Small States Revisited: A
Study of Singapore's Post-Cold War Foreign Policy, Ann Arbor: University of Michigan Press, 1999; M. Leifer, Singapore's Foreign Policy. Coping with Vulnerability, OxonNew York: Rouledge, 2006; A. Acharya, Singapore's Foreign Policy. The Search For Regional Order, Singapore: Institute of Southeast Asian Studies, 2007; N. Ganesan, Realism and Interdependence in Singapore's Foreign Policy, London-New York: Rouledge, 2006.

[5] J.N. Rosenau, The Study of Political Adaptation, LondonNew York: Francis Printer Publishers, 1981, pp. 3-5.

[6] Z.J. Pietraś, Strategie adaptacji państw do środowiska międzynarodowego, Lublin: Wydawnictwo Uniwersytetu Lubelskiego, 1989, p. 19.

[7] T. Łoś-Nowak, Stosunki międzynarodowe. Teorie-systemyuczestnicy, Wrocław: Wydawnictwo Uniwersytetu Wrocławskiego, 2006, p. 289.

[8] J.N. Rosenau, Foreign Policy as Adaptive Behaviour, "Comparative Politics" 1970, vol. 2, p. 366; T. Łoś-Nowak, Stosunki międzynarodowe. Teorie-systemy-uczestnicy, Wrocław: Wydawnictwo Uniwersytetu Wrocławskiego, 2006, p. 290.

[9] T. Łoś-Nowak, Stosunki międzynarodowe. Teorie-systemyuczestnicy, Wrocław: Wydawnictwo Uniwersytetu Wrocławskiego, 2006, pp. 290-291.

[10] See S. Smith, Rosenau's Adaptive Behaviour Approach: A Critique, "Review of International Studies" 1981, vol. 7, no. 2, pp. 107-126; J.C. Suprewicz, Koncepcje adaptacji społecznej, in: Z.J. Pietraś, A. Dumała (eds), Mechanizmy adaptacji politycznej państwa, Lublin: Wydawnictwo Uniwersytetu Lubelskiego, 1990, p. 87.

[11] T. Łoś-Nowak, Stosunki międzynarodowe. Teorie-systemyuczestnicy, Wrocław: Wydawnictwo Uniwersytetu Wrocławskiego, 2006, pp. 291-292.

[12] T. Łoś-Nowak, Stosunki międzynarodowe. Teorie-systemyuczestnicy, Wrocław: Wydawnictwo Uniwersytetu Wrocławskiego, 2006, p. 292.

[13] J.N. Rosenau, Introduction: New Directions and Recurrent Questions in the Comparative Study of Foreign Policy, in: Ch.F. Hermann, Ch.W. Kegley, J.N. Rosenau (eds), New Directions in the Study of Foreign Policy, Boston: Allen\&Unwin, 1987, p. 6.

[14] See for example Z.J. Pietraś, Procesy adaptacji politycznej, Lublin: Wydawnictwo Uniwersytetu Lubelskiego,1990; Z.J. Pietraś, Koncepcje adaptacji politycznej, in: Z.J. Pietraś, A. Dumała (eds), Mechanizmy adaptacji politycznej państwa, Lublin: Wydawnictwo Uniwersytetu Lubelskiego, 1990.

[15] T. Łoś-Nowak, Stosunki międzynarodowe. Teorie-systemyuczestnicy, Wrocław: Wydawnictwo Uniwersytetu Wrocławskiego, 2006, p. 290.

[16] T. Łoś-Nowak, Stosunki międzynarodowe. Teorie-systemyuczestnicy, Wrocław: Wydawnictwo Uniwersytetu Wrocławskiego, 2006, p. 290.

[17] H.C. Chan, Singapore: the Politics of Survival, 1965-1967, Singapore: Institute of Southeast Asian Studies, 1971.

[18] S. Rajaratnam, Singapore: Global City, speech on 6 of February, 1972. 
[19] B.H. Lee, Constraints on Singapore's Foreign Policy, "Asian Survey" 1982, vol. 22, no. 6, p. 526.

[20] B.H. Lee, Constraints on Singapore's Foreign Policy, "Asian Survey" 1982, vol. 22, no. 6, p. 528.

[21] M. Leifer, Singapore's Foreign Policy. Coping with Vulnerability, Oxon-New York: Routledge, 2006, pp. 10-11.

[22] M. Leifer, Singapore's Foreign Policy. Coping with Vulnerability, Oxon-New York: Routledge, 2006, p. 11.

[23] Singapore Diplomatic Handbook, Washington: International Business Publication, 2008, p. 93.

[24] B.H. Lee, Constraints on Singapore's Foreign Policy, "Asian Survey" 1982, vol. 22, no. 6, p. 528.

[25] See A.W. Simpson, Small States in World Politics, "Cambridge Review of International Relations" 2006, vol. 19, no. 4; A. Chong, M. Maass, Introduction: the Foreign Policy Power of Small States, "Cambridge Review of International Affairs" 2010, vol. 23, no. 3.

[26] T. Koh, The Tommy Koh Reader. Favourite Essays and Lectures, Singapore: World Scientific, 2013, p. 186.

[27] T. Koh, The Tommy Koh Reader. Favourite Essays and Lectures, Singapore: World Scientific, 2013, p. 187.

[28] Cf. A. Acharya, Asia Rising: Who Is Leading?, Singapore: World Scientific, 2008, pp. 109-110.

[29] T. Koh, The Tommy Koh Reader. Favourite Essays and Lectures, Singapore: World Scientific, 2013, p. 189.

[30] The Idea of Singapore, "Commentary" 2013, vol. 22, pp. 3640; T. Koh, The Tommy Koh Reader. Favourite Essays and Lectures, Singapore: World Scientific, 2013, p. 189.

[31] Information available on the website: www.mfa.gov.sg.

[32] See K.W. Chin, Singapore's Perspective on Security Cooperation in the Asia-Pacific, in: S.S. Tan, A. Acharya, AsiaPacific Security Cooperation: National Interests and Regional Order, Oxon-New York: Routledge, 2004, pp. 174-179; Y.-K. Heng, W. Ong, The Quest for Relevance in Times of Peace: Operations Other Than War and the Third-Generation Singapore Armed Forces, in: C. Aoi, Y.-K. Heng (eds), AsiaPacific Nations in International Peace Support and Stability Missions, New York: Palgrave MacMillan, 2014, pp. 141-165.

[33] Information available on the website: www.sif.org.sg.

[34] A. Acharya, Singapore's Foreign Policy. The Search For Regional Order, Singapore: Institute of Southeast Asian Studies, 2007, pp. 28-29.

[35] B.H. Lee, Constraints on Singapore's Foreign Policy, "Asian Survey" 1982, vol. 22, no. 6, pp. 531-532.

[36] See J. Wong et al., A Study On Singapore's Experience In Regional Cooperation, Report by the East Asian Institute of the National University of Singapore, Singapore 2008.

[37] B.H. Lee, Constraints on Singapore's Foreign Policy, “Asian Survey" 1982, vol. 22, no. 6, p. 529.

[38] S. Rajaratnam, C.G. Kwa, S. Rajaratnam on Singapore: From Ideas to Reality, Singapore: World Scientific Publishing, 2006, p. 84 .
[39] S. Rajaratnam, C.G. Kwa, S. Rajaratnam on Singapore: From Ideas to Reality, Singapore: World Scientific Publishing, 2006, p. 85 .

[40] A. Acharya, Asia Rising: Who Is Leading?, Singapore: World Scientific, 2008, p. 112.

[41] H.J. Kim, P.P. Lee, The Changing Role of Dialogue in the International Relations of Southeast Asia, "Asian Survey" 2011, vol. 51, no. 5, p. 953 .

[42] See H.J. Kim, P.P. Lee, The Changing Role of Dialogue in the International Relations of Southeast Asia, "Asian Survey" 2011, vol. 51, no. 5, p. 954.

[43] R.C. Severino, Southeast Asia in Search of an ASEAN Community, Singapore: Institute of Southeast Asian Studies, 2006, pp. 11-17.

[44] H.J. Kim, P.P. Lee, The Changing Role of Dialogue in the International Relations of Southeast Asia, "Asian Survey" 2011, vol. 51, no. 5, p. 956; A. Acharya, Constructing a Security Community in Southeast Asia: ASEAN and the Problems of Regional Order, London: Routledge, 2001, pp. $47-49$.

[45] A. Acharya, Singapore's Foreign Policy. The Search For Regional Order, Singapore: Institute of Southeast Asian Studies, 2007, pp. 29-30.

[46] T.C. Daquila, H.H. Le, Singapore and ASEAN in the Global Economy: The Case of Free Trade Agreements, "Asian Survey" 2003, vol. 43, no. 6, p. 909.

[47] T.C. Daquila, H.H. Le, Singapore and ASEAN in the Global Economy: The Case of Free Trade Agreements, "Asian Survey" 2003, vol. 43, no. 6, pp. 911-914.

[48] J. Ravenhill, Economic Cooperation in Southeast Asia: Changing Incentives, "Asian Survey" 1995, vol. 35, no. 9, p. 863.

[49] M.H. Ting, Singapore's Foreign Policy Beyond Realism, Thesis submitted to the University of Adelaide, 2010, p. 20.

[50] Cf. E.C. Thompson, Singaporean Exceptionalism and Its Implications for ASEAN Regionalism, "Contemporary Southeast Asia" 2006, vol. 28, no. 2, pp. 183-206.

[51] A. Acharya, Singapore's Foreign Policy. The Search For Regional Order, Singapore: Institute of Southeast Asian Studies, 2007, p. 25.

[52] See B. Skulska, Nowy regionalizm w Azji Wschodniej, "Stosunki Międzynarodowe-International Relations" 2011, vol. 44, no. 3-4, pp. 93-116.

[53] See J. Parsonage, The State and Globalization: Singapore's Growth Triangle Strategy, Perth: Murdoch University, 1994.

[54] A. Acharya, Singapore's Foreign Policy. The Search For Regional Order, Singapore: Institute of Southeast Asian Studies, 2007, pp. 25-26.

[55] J. Wong et al., A Study On Singapore's Experience In Regional Cooperation, Report by the East Asian Institute of the National University of Singapore, Singapore: Institute of Southeast Asian Studies, 2008, p. 27.

[56] J. Wong et al., A Study On Singapore's Experience In Regional Cooperation, Report by the East Asian Institute of the National University of Singapore, Singapore: Institute of Southeast Asian Studies, 2008, p. 29. 
[57] A. Latif, Between Rising Powers: China, Singapore and India, Singapore: World Scientific, 2007.

[58] A. Acharya, Asia Rising: Who Is Leading?, Singapore: World Scientific, 2008, p. 110.

[59] See A. Acharya, The Quest for Identity. International Relations of Southeast Asia, Oxford: Oxford University Press, 2000 .

[60] The research included respondent from Indonesia, Malaysia, Singapore, Thailand, Vietnam and the Philippines. Respondents speak English and live in the cities.

[61] Cf. A. Acharya, The Quest for Identity. International Relations of Southeast Asia, Oxford: Oxford University Press, 2000.

[62] A. Acharya, Singapore's Foreign Policy. The Search For Regional Order, Singapore: Institute of Southeast Asian Studies, 2007, p. 111.

[63] See L. Suryadinata (ed.), Southeast Asia's Chinese Businesses in an Era of Globalization: Coping with the Rise of China, Singapore: Institute of Southeast Asian Studies, 2006; L. Suryadinata, "Overseas Chinese" in Southeast Asia and China's Foreign Policy. An Interpretative Essay, Singapore: Institute of Southeast Asian Studies, 1978.

[64] A. Acharya, Singapore's Foreign Policy. The Search For Regional Order, Singapore: Institute of Southeast Asian Studies, 2007, p. 115.

[65] A. Acharya, Singapore's Foreign Policy. The Search For Regional Order, Singapore: Institute of Southeast Asian Studies, 2007, pp. 115-116.

[66] L. Thio, Implementing Human Rights in ASEAN Countries: "Promises to Keep and Miles to Go Before I Sleep", "Yale Human Rights and Development Journal" 1999, vol. 2, no. 1, p. 1.
[67] H.-L. Tan, The ASEAN Intergovernmental Commission on Human Rights: Institutionalising Human Rights in Southeast Asia, Cambridge: Cambridge University Press 2011.

[68] 'Our Approach', MARUAH: Working Group for an ASEAN Human Rights Mechanism, www.maruah.org.

[69] See L. Lyons (ed.), A State of Ambivalence: The Feminist Movement in Singapore, Leiden: Brill, 2004.

[70] After H.-L. Tan, The ASEAN Intergovernmental Commission on Human Rights: Institutionalising Human Rights in Southeast Asia, Cambridge: Cambridge University Press, 2011, p. 134.

[71] Singapore Prime Minister Lee Backs Trans Pacific Partnership and Stronger U.S. Ties. A Conversation with Lee Hsien Loong, 25 June, 2014, dostęp: http://www.cfr.org/singapore/singapore-prime-minister-leebacks-trans-pacific-partnership-stronger-us-ties/p33178.

[72] J.-L. Margolin, Singapore: New Regional Influence, New World Outlook?, "Contemporary Southeast Asia" 1998, vol. 20, no. 3 .

[73] R. Katanyuu, Beyond Non-Interference in ASEAN: The Association's Role in Myanmar's National Reconciliation and Democratization, “Asian Survey” 2006, vol. 46, no. 6, p. 838.

[74] R. Katanyuu, Beyond Non-Interference in ASEAN: The Association's Role in Myanmar's National Reconciliation and Democratization, “Asian Survey” 2006, vol. 46, no. 6, p. 839.

[75] H.-L. Tan, The ASEAN Intergovernmental Commission on Human Rights: Institutionalising Human Rights in Southeast Asia, Cambridge: Cambridge University Press 2011, pp. 134135.

[76] H.C. Chan, Friends and Ideas in Diplomacy, "Straits Times", 29 August, 2005. 